\title{
Seedling physiological responses from Ceiba glaziovii (Kutze) K. Skum. to intermittent drought events
}

\author{
Maria Fernanda da Costa Oliveira ${ }^{\mathrm{a}^{*} \oplus}$, José Laurindo dos Santos Júnior ${ }^{\mathrm{a}}{ }^{\oplus}$, Rafael Silva Freitas ${ }^{\mathrm{b}} \oplus$, \\ Elizamar Ciríaco da Silva ${ }^{a}$
}

a Universidade Federal de Sergipe, Brasil

b Universidade Federal de Viçosa, Brasil

*Autor correspondente (mfdacostaoliveira@gmail.com)

\section{N F O}

\section{Keyworks}

barriguda

Caatinga

plasticity

\section{Palavras-chaves}

barriguda

Caatinga

plasticidade

\section{A B S T R A C T}

The Brazilian Dry Tropical Forest, called Caatinga, has several environmental conditions limiting plant growth and development, requiring the plants that inhabit this phytogeographic domain, physiological and morphological traits to guarantee the perpetuation and survival of the species. The objective of the present work was to evaluate the growth parameters in Ceiba glaziovii, a tree species that occurs in the Caatinga, submitted to intermittent drought. For such seedling of $C$. glaziovii were subjected to different cycles of irrigation suspension [Control- daily irrigation, S7- irrigation every seven days and SS - total suspension of irrigation until signs of wilt appear]. Height, number of leaves, stem diameter, dry matter of the various organs, root / shoot ratio, leaf area, and the index of plasticity were evaluated. The prolongation of intermittent drought had a significant reducing effect on the growth rates, dry matter production and leaf area of stressed C. glaziovii seedlings compared to daily watering ones. Plant height and stem diameter were the most plastic traits found (IP $>0,8)$. Thus, watering intervals above seven days may severely compromise the production of $C$. glaziovii seedlings, affecting the growth rates until the accumulation of dry matter. These results demonstrate that this species does not show great tolerance to drought stress during the initial period of its development, suggesting for cultivation of seedlings an adequate water availability or an interval of up to seven days between watering.

\section{R E S U M O}

Respostas fisiológicas de mudas de Ceiba glaziovii (Kutze) K Skum. à eventos de seca intermitente. A Floresta Tropical Seca brasileira, chamada de Caatinga, apresenta diversas condições ambientais que limitam o crescimento e desenvolvimento dos vegetais, exigindo das plantas que habitam esse domínio fitogeográfico estratégias morfológicas e fisiológicas que garantam a perpetuação e sobrevivência de suas espécies. O objetivo deste trabalho foi avaliar os parâmetros do crescimento inicial de Ceiba glaziovii, espécie arbórea que ocorre na Caatinga, submetidas a seca intermitente. Para tal, plântulas de $C$. glaziovii foram submetidas a diferentes ciclos de suspensão de rega [rega diária (controle), a cada sete dias (S7) e suspensão da rega até sinais de murcha foliar (SS). Foram avaliados altura, número de folhas, diâmetro do caule, matéria seca dos diversos órgãos, relação raiz/ parte aérea, área foliar, e o índice de plasticidade. $\mathrm{O}$ prolongamento da seca intermitente apresentou um efeito significativamente redutor nos ritmos de crescimento, na produção de matéria seca e na área foliar das plântulas de C. glaziovii estressadas em comparação as regadas diariamente. A altura e o diâmetro do caule das mudas foram as características mais plásticas encontradas (IP>0,8). Não houve diferença para partição de biomassa e relação raiz/parte aérea. Com isso, intervalos de rega acima de sete dias podem comprometer a produção de mudas de C. glaziovii, demonstrando que a espécie não apresenta grande tolerância a seca durante o período inicial do seu desenvolvimento. É indicado o cultivo das mudas em situações de disponibilidade hídrica ou intervalo de até sete dias entre as regas. 


\section{INTRODUCTION}

Northeastern Brazil has about 53\% of the semiarid region, in which it is inserted the ecoregion called Caatinga, one of the geographical domains occurring in dry tropical forests (Dombroski et al., 2011; Santos et al., 2021). This domain is characterized by a low annual precipitation volume (250-800 mm) distributed irregularly, and high soil and air temperatures. These characteristics can promote changes in the distribution of plant communities in the most diverse ecosystems (Silva et al., 2017; Zhao et al., 2018).

Because of the intensification of the greenhouse effect caused by global climate changes, arid and semi-arid environments have been considered highly vulnerable to climate changes (Ouhamdouch e Bahir, 2017; Marengo et al., 2018). In this perspective, the Caatinga vegetation has undergone severe changes caused by desertification and anthropic actions, putting at risk the promotion of the maintenance of ecosystem services and the permanence of these species (Silva et al., 2017; Antongiovanni et al., 2020; Ramos et al., 2020).

Several findings in the literature have been discussing the most varied strategies that plants occurring in arid and semi-arid environments are used to withstand this recurrent disturbance (Silva et al., 2013; Gratani, 2014; Amissah et al., 2018; Santos Júnior et al., 2020; Ribeiro et al., 2020). Some changes in growth patterns such as reduced number of leaves and leaf area (Moura et al., 2020), investments in a more robust root system (Dantas et al., 2020) and, consequently, increase in the root/shoot ratio (Ferreira et al., 2015) have been interpreted as important morphological transformations that guarantee greater survival in these environments (Santos Júnior et al., 2020).

Although these changes occur, it is still questionable whether such characteristics, which are often indications of xeromorphic behavior, are common among the most diverse species that are already adapted to these environmental conditions (Souza et al., 2015; Santos et al., 2021). This leads us to question whether the occurrence of this behavior is closely related to the plant's growth habit or it is a consequent response to the stressful environment.

Ceiba glaziovii (Kutze) K. Sckum, known as paunchy or white paineira, it is an endemic tree species from northeastern Brazil, occurring in the Caatinga (Duarte, 2015; Silva et al., 2021). Its popular name is due to its great ability to retain water in its stem, leaving it swollen (Du Bocage e Sales, 2002; Silva et al., 2016). The species in question has a strong importance for popular knowledge due to its medicinal properties (PereiraJúnior et al., 2014), helping in predicting rainfall
(Bastos e Fuentes, 2015), feeding ruminants (Souza et al., 2013) and it has also been shown to be important in projects for the restoration of degraded areas (Lorenzi, 2009; Pereira et al., 2001).

Notwithstanding the conditions of the phytogeographic domain of occurrence of the species and its natural tolerance to conditions of strict water limitation, studies that evaluate the morphological parameters of its initial growth, in this perspective, are scarce, with studies under different levels of shading (Ribeiro et al., 2020) or studying other aspects of their behavior under intermittent drought (Santos Júnior et al., 2020).

Therefore, the present study aimed to evaluate the growth parameters of Ceiba glaziovii seedlings submitted to intermittent drought, seeking to discuss how the morphological responses reflect in different growth patterns and rhythms for the ecology and survival of this species.

\section{MATERIAL AND METHODS}

The experiment was conducted out under semicontrolled conditions in an agricultural greenhouse at the Federal University of Sergipe (UFS). The seeds of Ceiba glaziovii K. was collected in Paripiranga/BA ( $\left.10^{\circ} 41^{\prime} 00^{\prime \prime} \mathrm{S} ; 37^{\circ} 51^{\prime} 00^{\prime \prime} \mathrm{O}\right)$, located in a semi-arid region, and sown in trays containing washed sand.

After emergence, fifteen seedlings they were transplanted into polyethylene bags containing 4.5 $\mathrm{kg}$ of a mixture of vegetable soil, washed sand, and bovine manure, in the proportion 3:1:1 (v/v). The seedlings, after transplanting, were watered daily for approximately 20 days, close to field capacity (20\% of the maximum volumetric capacity of the soil), before the application of water treatments (differentiation of treatments).

Soil monitoring was done using a soil meter (Hidrofarm HFM2010 Falker), and the soil remained close to field capacity with an average percentage of volumetric soil moisture of $20.9 \%$.

During the period of the experiment, the average temperature was $29.6{ }^{\circ} \mathrm{C}$, ranging from $25.9^{\circ} \mathrm{C}$ to $31.3^{\circ} \mathrm{C}$. The average relative humidity was $64.8 \%$, alternating from 49 to 75 .

The experimental design was completely randomized, with three water treatments of irrigation suspension cycles [daily watering (control), intervals of seven days as moderate stress (S7), and suspension of watering until signs of leaf wilt as severe stress (SS)] with five replication per treatment, totaling 15 seedlings.

Soil moisture was always assessed before reirrigation in all treatments. The vegetative growth was evaluated weekly over the 56 days, and the parameters evaluated were: height of the seedlings 
$(\mathrm{H})$, using a measuring tape, starting from the base of the stem at a previously marked point until the insertion of the youngest leaf; basal stem diameter (SD), using a Digimess digital caliper measuring it in a previously marked location, and the number of leaves (LN) from the visual count.

At the end of the experimental period, the seedlings were separated into leaves, stem and root, packed in paper bags and taken to dry in an oven at $65^{\circ} \mathrm{C}$ for 72 hours until the material reached constant weight, to obtain the dry matter weight for leaves (LDM), stem (SDM), root (RDM) and total (TDM). From these data, it was possible to calculate the biomass partition for the various organs and the root/shoot ratio (R/S ratio), following the protocols described by Benincasa (2003).

The phenotypic plasticity index (ranging from 0 to 1) for each morphological variable was calculated as resulting from the difference between the highest and lowest mean values between treatments, divided by the highest mean value.

Values closer to 1 indicate high levels of plasticity for a given characteristic, whereas values close to 0 indicate low levels of plasticity for the analyzed attribute (Valladares et al., 2005). The data were submitted to the Shapiro-Wilk normality test and when the data presented normal distribution they were subjected to analysis of variance and the means compared by the Tukey $(\mathrm{P}<0,05)$.

\section{RESULTS AND DISCUSSION}

The soil moisture was reduced over the experimental period due to intermittent drought, both due to evaporative issues occurring on the surface of the pots and due to the water demands of the seedlings in the respective water treatments.

The reduction in water availability directly affects the development and physiology of plants, being a relevant factor for the survival of species that live under this stress condition (Taiz et al., 2017; Marengo et al., 2018).

The soil moisture of the control seedlings (C) ranged from 19.2 to $20.9 \%$, whereas in the seedlings watered every seven days (S7) the variation was from 15.8 to $16.9 \%$ and in plants with water suspension. watering until signs of leaf wilting (SS) varied from $9.3 \%$ to $9.6 \%$, before reirrigation, which demonstrates a reduction of about 20 and $50 \%$ in soil moisture, for plants grown under moderate water restriction and severe, respectively, when compared to the control treatment (Table 1).

Table 1 - Percentage of volumetric soil moisture (\%) before the re-irrigation of $C$. glaziovii seedlings subjected to intermittent drought. Control (C) with daily watering, watering every seven (S7) day sand at intervals until the leaves show signs of wilting (SS). Mean \pm SD of five repetitions

\begin{tabular}{cccc}
\hline \multirow{2}{*}{ Days after water stress } & C & S7 & SS \\
\cline { 2 - 4 } 14 & $19,2 \pm 0,5$ & $16,3 \pm 0,6$ & - \\
& & & $9,4 \pm 0,7$ \\
28 & $20,9 \pm 2,4$ & $16,0 \pm 2,0$ & $9,3 \pm 0,3$ \\
& & & \\
42 & $19,1 \pm 1,2$ & $16,4 \pm 0,9$ & $9,4 \pm 0,4$ \\
56 & $20,8 \pm 1,0$ & & \\
Mean & $\mathbf{2 0 , 9 \pm 0 , 0 4}$ & $15,8 \pm 0,4$ & $9,6 \pm 0,4$ \\
& & $\mathbf{1 6 , 0 5} \pm \mathbf{1 , 4}$ & $\mathbf{9 , 5} \pm \mathbf{0 , 0 6}$ \\
\hline
\end{tabular}

The water deficit in the soil is one of the main abiotic factors that affect the establishment and dynamics of plant species, affecting the growth rates and production of dry matter in the initial stage of plant development (Silva et al., 2013; Gratani, 2014; Ribeiro et al., 2019; Santos Júnior et al., 2020).

In this study, there was a marked reduction in growth rates in seedlings of $C$. glaziovii as they were exposed to more severe water restriction, which reflected drastic reductions in the final accumulation of fixed carbon. Seedlings grown under the highest water restriction regime showed approximately $70 \%$ reduction in height and stem diameter (Figure 1A and 1B), as well as 50\% reduction in the number of leaves when compared to the control treatment (Figure 1C). Analyzing the growth of Erythrina velutina seedlings De Oliveira et al., (2016) also observed reductions in height and number of leaves when grown under water restrictions. Reductions in cell division rates during periods of water restriction may imply a decrease in plant growth rate (Taiz et al., 2017). 


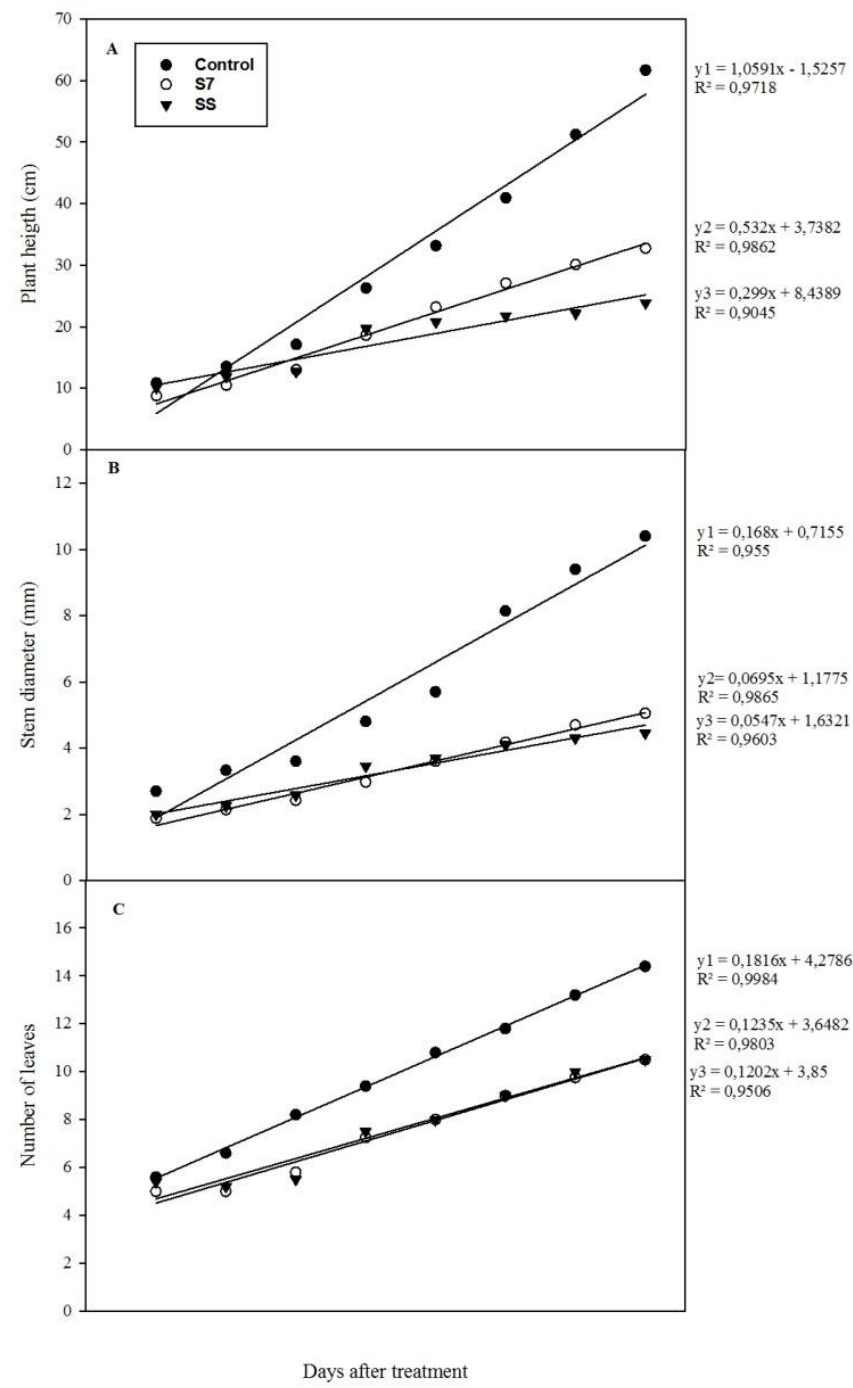

Figure 1 - Height (A), basal stem diameter (B) and leaf number (C) of C. glaziovii seedlings submitted to intermittent drought

This behavior of reduced growth rates was also observed in moderate stress. These reductions in height, stem diameter, and, especially, the number of leaves can harm the production of dry matter. Thus, leaf abscission may be one of the survival mechanisms used during water scarcity, found in some arboreal species such as Tabebuia aurea and Caesalpinia ferrea (Dombroski et al., 2011) but the species in the present study did not use this strategy but significantly reduced the emission of new leaves when they were stressed.

Similar to growth, intermittent drought had a strong effect on the production of dry matter (Table 2 ), especially on root (RDM) and total (TDM) dry matter. The most severe watering intervals (SS), of approximately 14 days, significantly reduced the production of dry matter when compared to the control seedlings $(\mathrm{C})$, reductions also observed to plants watered each every seven days (S7). No significant results were observed for the root/shoot ratio and biomass partition for the different organs. The interferences of water deficit in the promotion of growth and development rhythms in plants as observed in the present work have been widely discussed (Silva et al., 2013; Gratani, 2014; De Oliveira et al., 2016; Taiz et al., 2017; Santos Júnior et al., 2020). 
Table 2 - Leaves dry mass (LDM), stem dry mass (SDM), root dry mass (RDM), total dry mass (TDM), root/shoot ratio (R/S), leaf biomass partition (LBP), stem biomass partition (SBP) and root biomass partition (RPB) of C. glaziovii seedlings submitted to water deficit. Control, S7 and SS corresponding to water treatments as daily watering and intervals of seven days and total suspension of watering, respectively. Equal letters did not differ statistically by Tukey's test $(\mathrm{P}<0.05)$

\begin{tabular}{ccccccccc}
\hline $\begin{array}{c}\text { Water tre- } \\
\text { atment }\end{array}$ & $\begin{array}{c}\text { LDM } \\
(\mathbf{g})\end{array}$ & $\begin{array}{c}\text { SDM } \\
(\mathbf{g})\end{array}$ & $\begin{array}{c}\text { RDM } \\
(\mathbf{g})\end{array}$ & $\begin{array}{c}\text { TDM } \\
(\mathbf{g})\end{array}$ & R/S ratio & $\begin{array}{c}\text { LPB } \\
(\boldsymbol{\%})\end{array}$ & $\begin{array}{c}\text { SPB } \\
(\boldsymbol{\%})\end{array}$ & $\mathbf{R P B}(\boldsymbol{\%})$ \\
\hline Control & $3,96 \mathrm{a}$ & $4,32 \mathrm{a}$ & $5,13 \mathrm{a}$ & $11,12 \mathrm{a}$ & $0,3944 \mathrm{a}$ & $29,12 \mathrm{a}$ & $43,54 \mathrm{a}$ & $27,32 \mathrm{a}$ \\
$\mathbf{S 7}$ & $2,68 \mathrm{a}$ & $3,49 \mathrm{a}$ & $2,35 \mathrm{~b}$ & $5,33 \mathrm{~b}$ & $0,3478 \mathrm{a}$ & $28,64 \mathrm{a}$ & $46,29 \mathrm{a}$ & $25,05 \mathrm{a}$ \\
$\mathbf{S S}$ & $1,05 \mathrm{~b}$ & $1,90 \mathrm{~b}$ & $1,02 \mathrm{~b}$ & $3,94 \mathrm{~b}$ & $0,3271 \mathrm{a}$ & $27,14 \mathrm{a}$ & $46,35 \mathrm{a}$ & $26,50 \mathrm{a}$ \\
\hline
\end{tabular}

These reductions in growth rates are multicausal in nature and may occur due to stomatal limitations (Santos Júnior et al., 2020), which aim to restrict the loss of water through transpiration while limiting the diffusion of $\mathrm{CO}_{2}$ to the carboxylation sites, reducing the formation of carbon compounds for immediate consumption and promoting growth rates (Marques et al., 2020; Santos et al., 2021) commented that Ceiba glaziovii seedlings under intermittent drought prioritize keeping the tissues hydrated, probably due to stomatal closure, slowing their growth to ease metabolic costs.

Reductions in growth rates are also related to the adoption of energetically costly mechanisms such as the accumulation of osmoprotective and regulatory substances that aim to protect tissue water content (Moura e Vieira, 2020; Santos Júnior et al., 2020), a characteristic that Ceiba glaziovii presents in the roots to keep the tissues hydrated at the first sign of drought (Santos Júnior et al., 2020).

In addition, the absence of the basic preceptor maintain growth rates. The absence of water hinders the processes of cell stretching and division, which leads to a restriction of cell expansion since it is the one that guarantees the necessary turgor pressure for cell growth to occur (Taiz et al., 2017).

Although this occurs, some of the usual responses to this condition were not observed in the present study, such as greater root growth resulting from a greater investment of resources for this organ. This generally translates into changes in the proportion of root growth as a function of the area, which is usually interpreted as xeromorphic behavior. This can guarantee a greater uptake of water resources in the deepest layers of the soil as well as better management of the transpiring surfaces (Ferreira et al., 2015; Dantas et al., 2020). Thus, although $C$. glaziovii is a species widely occurring in the semi-arid landscapes of the Caatinga, it does not seem to use this strategy of reversing patterns to deal with disturbances occurring in its place of occurrence.

Despite the literature citing the inversion of growth patterns as a drought tolerance strategy, species such as popularly called jatobá (Hymenea coubaril L.) (Nascimento et al., 2011) and pereiro (Aspidosperma pyrifolium Mart.) (Freitas e Silva, 2018) in the same way that $C$. glaziovii also does not present such alterations. This behavior, at least so that $H$. courbaril and $A$. pyrifolium seems to be related to the low growth rates that these species have, presenting a slow growth pattern in the initial stage of development, which does not seem to apply to $C$. glaziovii, since it is referred to as a selective xerophytic pioneer species (Melo et al., 2014), which in a way needs further explanation.

Some changes in leaf morphology and structure respond to water deficiency. In the present study (Table 3), an increase in the leaf area ratio (LAR) was noted, a characteristic that demonstrates changes in leaf thickness, which may symbolize a greater accumulation of carbohydrates or inefficiency in transporting them (Benincasa, 2003; Nascimento et al., 2011). In addition, changes in specific leaf area (SLA) seems to correlate with interferences in carbon metabolism, requiring a larger leaf area to maintain full photosynthetic capacity, at least in conditions of moderate stress. 
Table 3 - Leaf area (LA) $\left(\mathrm{cm}^{2}\right)$, leaf area ratio (LAR) $\left(\mathrm{cm}^{2} / \mathrm{g}\right.$ TDM) and specific leaf area (SLA) $\left(\mathrm{cm}^{2} / \mathrm{g}\right.$ LDM) of $C$. glaziovii seedlings submitted to water deficit. Equal letters did not differ statistically by Tukey's multiple range test $(\mathrm{P}<0.05)$
Water treatment
$\mathbf{L A}\left(\mathbf{c m}^{2}\right)$
LAR $\left(\mathrm{cm}^{2} / \mathrm{g}\right.$ TDM $)$
SLA $\left(\mathrm{cm}^{2} / \mathrm{g} \mathrm{LDM}\right)$

\begin{tabular}{cccc}
\hline Control & $267,6 \mathrm{a}$ & $18,5 \mathrm{~b}$ & $74,9 \mathrm{ab}$ \\
S7 & $230,2 \mathrm{a}$ & $21,5 \mathrm{ab}$ & $77,0 \mathrm{a}$ \\
SS & $140,1 \mathrm{~b}$ & $25,0 \mathrm{a}$ & $62,0 \mathrm{~b}$ \\
\hline
\end{tabular}

Plant species that have a slow-growing initial growth, especially late secondary and climax (Lovelock et al., 1998), do not invest as many resources in promoting the growth of a given organ, thus impacting on low levels of plasticity for such characteristics. This behavior seems to be related to the ecology of tree species, since such organisms do not require high levels of energy investment for faster growth (reflecting a lower level of plasticity), which no longer occurs with fast-growing species that require a large amount of resources to develop in a short period of time, which reflects a high degree of plasticity (Chapin III et al., 1993; Price et al., 2003 Ferreira et al., 2015).
Although we have observed this fact, in our study changes in height and stem diameter were the characteristics of greater plasticity (Figure 2 ). The plastic response of such organs probably seems to be related to the particularity of the growth habit of C. glaziovii, which presents differentiated stem anatomy. It can store large volumes of water, a stock that guarantees the maintenance of the water supply during periods of drought.

Thus, it is notable that this curious strategy of living with drought requires organs with high levels of plasticity, which allows expansion and retraction of the stem without serious damage to the anatomical structures.

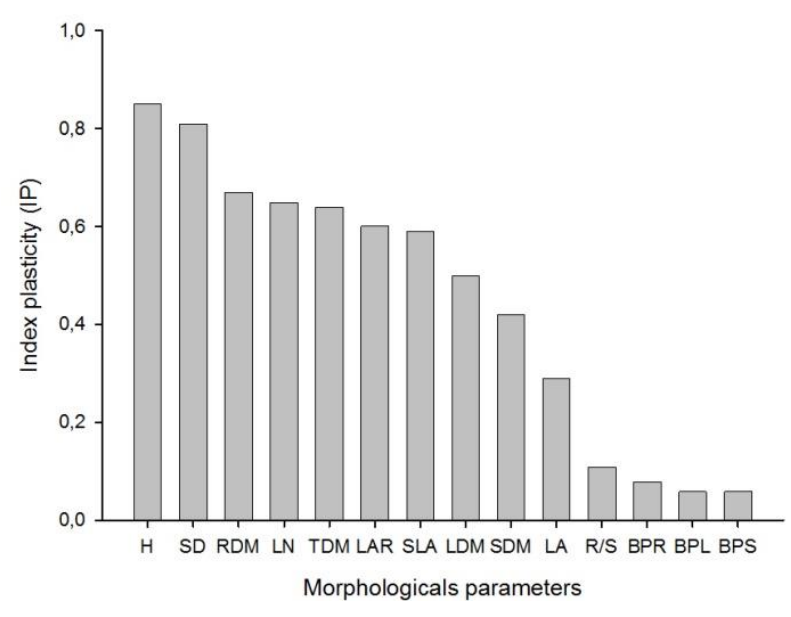

Figure 2 - Plasticity index of the morphological parameters evaluated in C. glaziovii seedlings submitted to intermittent drought. Height $(\mathrm{H})$, stem diameter (SD), root dry matter (RDM), leaf number (LN), total dry matter (TDM), leaf area ratio (LAR), specific leaf area (SLA), leaf dry matter (LDM), stem dry matter (SDM), leaf area (LA), root/shoot ratio (R/S), biomass partitioning for root (BPR), biomass partitioning for leaves (BPL), and biomass partitioning for stem (BPS) 
In this study, C. glaziovii had its initial growth reduced when subjected to severe water stress, which highlights the importance of studies on the morphophysiological responses of plants during the seedling establishment phase, ensuring a higher success rate in reforestation programs. Therefore, evaluating the initial parameters of seedling growth is of significant importance in identifying the strategies used by species to establish themselves in environments with unfavorable situations. In this way, it is possible to contribute to higher productivity of seedlings, knowing the conditions that best favor their growth, inducing greater amounts of acclimated plants to the various stressful situations found in the Caatinga, thus increasing the percentage of success of their insertion environment.

\section{CONCLUSIONS}

Ceiba glaziovii is moderately tolerant to water suppression during the initial phase of its development. Intervals longer than seven days compromise seedling production, by reducing growth and dry matter production. So, according to the present study the cultivation of the seedlings must be carried out with adequate water availability, using interval of up to seven days between irrigations.

\section{ACKNOWLEDGMENTS}

The authors would like to thank the Federal University of Sergipe for the scholarship granted through the Scientific Initiation Program (PIBIC) and to the Center for Ecology and Environmental Monitoring - NEMA/UNIVASF, the Integration Project of the São Francisco River with the NorthNortheast Hydrographic Basins - PISF and the Ministry of Regional Development - MDR.

\section{REFERENCES}

Amissah L, Mohren GMJ, Kyereh B, Agyeman VK, Poorter L. Rainfall seasonality and drought performance shape the distribution of tropical tree species in Ghana. Ecology and Evolution, v.8, p.8582-8597, 2018. https://doi.org/10.1002/ece3.4384

Antongiovanni M, Venticinque EM, Matsumoto M, Fonseca CR. Chronic anthropogenic disturbance on Caatinga dry forest fragments. Journal of Applied Ecology, v.57, p.2064-2074, 2020. https://doi.org/10.1111/13652664.13686

Bastos S, Fuentes MC. O uso da etnoclimatologia para a previsibilidade de chuvas no município de RetirolândiaBA. Revista do CERES, v. 1, n. 2, p. 176-183, 2015. Disponível em: http://www.cerescaico.ufrn.br/ceres/. Acesso em 17 mar. 2021.
Benincasa MMP. Análise de crescimento de plantas: noções básicas. Jaboticabal: FUNEP; 41p. 2003.

Chapin III FS, Autumn K, Pugnaire F. Evolution of suites of traits in response to environmental stress. The American Naturalist, v.142, p.79-92, 1993. https://doi.org/10.1086/285524

Dantas BF, Ribeiro RC, De Oliveira GM, Da Silva FFS, de Araújo GGL. Biosaline production of seedlings of native species from the Caatinga dry forest. Ciência Florestal, v.29, n.4, p.1551-1567, 2020. http://dx.doi.org/10.5902/1980509831221.

De Oliveira MKT, Dombroski JLD, de Medeiros RCA, de Medeiros AS. Desenvolvimento inicial de Erythrina velutina sob restrição hídrica. Pesquisa Florestal Brasileira, v.36, n. 88 , p.481-488, 2016. https://doi.org/10.4336/2016.pfb.36.88.1261.

Dombroski JLD, Praxedes S, Freitas RM, Pontes FM. Water relations of Caatinga trees in the dry season. South African Journal of Botany, v.77, p.430-434, 2011. https://doi.org/10.1016/j.sajb.2010.11.001.

Duarte, MC. 2015. Ceiba in Lista de espécies da flora do Brasil. Jardim Botânico do Rio de Janeiro. Disponível em: http://floradobrasil.jbrj.gov.br/jabot/floradobrasil/FB9 035 . Acesso em: 08 jan. 2021.

Du Bocage AL, Sales MF. A família Bombacaceae Kunth no Estado de Pernambuco, Brasil. Acta Botanica Brasilica, São Paulo, v.16, n.2, p.123-139, 2002. https://doi.org/10.1590/S0102-33062002000200001

Ferreira WN, Lacerda CF de, Costa RC, Medeiros FS. Effect of water stress on seedling growth in two species with different abundances: the importance of Stress Resistance Syndrome in seasonally dry tropical forest. Acta Botanica Brasilica, v.29, n.3, 2015. https://doi.org/10.1590/0102$33062014 a b b 0045$

Freitas RS, Silva EC. Respostas fisiológicas de mudas de Aspidosperma pyrifollium (Apocynaceae) à ciclos de suspensão de rega. Scientia Plena, v.14, n.5, p.1-12, 2018. https://doi.org/10.14808/sci.plena.2018.051201.

Gratani L. Plant Phenotypic plasticity in response to environmental factors. Advances in Botanica, v.2014, p.17, 2014. http://doi.org/10.1155/2014/208747.

Lorenzi H. Árvores brasileiras: manual de identificação e cultivo de plantas arbóreas nativas do Brasil. Nova Odessa, São Paulo: Editora Plantarum. v.2, 229p, 2009.

Lovelock CE, Winter K, Mersits R, Popp M. Responses of communities of tropical tree species to in elevated $\mathrm{CO}_{2}$ in a forest clearing. Oecologia, v.116, p.207-218, 1998. http://dx.doi.org/10. 1007/s004420050581

Marengo JA, Alves LM, Alvala RCS, Cunha AP, Brito S, Moraes OLL. Climatic characteristics of the 2010-2016 drought in the semiarid Northeast Brazil region. Annals of the Brazilian Academy of Sciences, v. 90, p. 1973-1985, 2018. http://dx.doi.org/10.1590/0001-3765201720170206

Marques I, Fernandes I, David PHC, Paulo OS, Goulao LF, Fortunato AS, Lidon FC, DaMatta FM, Ramalho JC, Ribeiro-Barros AI. Transcriptomic Leaf Profiling Reveals Differential Responses of the Two Most Traded Coffee Species to Elevated $\left[\mathrm{CO}_{2}\right]$. International Journal of 
Molecular Sciences, v.20, n.23, p.1-24, 2020. https://doi.org/10.3390/ijms21239211.

Melo AFR, Nogueira Junior LR, Guimarães MC, Amorim JRA. Semeadura direta de espécies arbóreas da Caatinga e Mata Atlântica na recomposição de áreas de reserva legal e mata ciliar no agreste sergipano: observações iniciais. In: Seminário de Iniciação científica e Pós-graduação da Embrapa Tabuleiros Costeiros, 2014, Aracaju. Disponível em: http://ainfo.cnptia.embrapa.br/digi-

tal/bitstream/item/110459/1/191.pdf. Acesso em 17 mar. 2021.

Moura GKA, Rufino MKG, Da Silva FKG, Trovão, DMBM. Leaf deciduousness and flowering of woody Caatinga species. Biotemas, v.33, n.4, p.1-10, 2020. http://dx.doi.org/10.5007/2175-7925.2020.e72364

Moura J, Vieira EA. Responses of Young plants of Vachellia farnesiana to drought. Australian Journal of Botany, v.68, p. 587-594, 2020. https://doi.org/10.1071/BT20043

Nascimento HHC, Nogueira RJMC, Da Silva EC, Da Silva MA. Análise do crescimento de mudas de jatobá (Hymenaea coubaril L.) em diferentes níveis de água no solo. Revista Árvore, v. 35, n. 3, p. 617-626, 2011. http://dx.doi.org/10.1590/S0100-67622011000400005

Ouhamdouch S, Bahir M. Climate Change Impact on Future Rainfall and Temperature in Semi-arid Areas (Essaouira Basin, Morocco). Environmental Processes, v.4, n.4, p. 116, 2017. https://doi.org/10.1007/s40710-017-0265-4

Pereira IM, De Andrade LA, Costa JRM, Dias JM. Regeneração natural em um remanescente de caatinga sob diferentes níveis de perturbação, no agreste paraibano. Acta Botanica Brasilica, v.15, n. 3, p.413-426, 2001. https://doi.org/10.1590/S0102-33062001000300010

Pereira Junior LR, Andrade AP, Araujo KD, Barbosa AS. Espécies da Caatinga como alternativa para o desenvolvimento de novos fitofármacos. Floresta e Ambiente, v.21, n.4, p.509-520, 2014. https://doi.org/10.1590/21798087.024212

Price TD, Qvarnstrom A, Irwin DE. The role of phenotypic plasticity in driving genetic evolution. Proceedings of the Royal Society B: Biological Sciences, v.270, n.1523, p.1433-1440,2003. https://doi.org/10.1098/rspb.2003.2372

Ramos GG, Alves JB, De Araújo MF, Ferreira VSG, Pinto MGC, Leite MJH. Survey of the environmental impacts of a ciliary forest stretch in the Caatingaregion in the Paraíbano hinterland. Brazilian Journal of Development, v.6, n.7, p.52848-52859, 2020. https://doi.org/10.34117/bjdv6n7-798

Ribeiro JES, Figueiredo FRA, Coêlho ES, Pereira WE, De Albuquerque MB. A non-destructive method for estimating leaf area of Ceiba glaziovii (Kuntze) K. Schum. Floresta, v.50, n.1, p.1063-1070, 2019. http://dx.doi.org/10.5380/rf.v50i1.61088

Ribeiro JES, Figueiredo FRA, Coêlho ES, Pereira WE, De Albuquerque MB. Ecophysiology of Ceiba glaziovii (Kuntze) K. Schum. submitted to shading. Journal of Agricultural Studies, v.8, n.2, p.182-194, 2020. https://doi.org/10.5296/jas.v8i2.15774

Santos Júnior JL, Oliveira MFC, Silva EC. Acúmulo de solutos orgânicos em mudas de Ceiba glaziovii (Kutze) Kum. em resposta à seca intermitente. Scientia Plena, v.16, n.1, p.1-12, 2020.

https://doi.org/10.14808/sci.plena.2020.011201.

Santos M, Barros V, Lima L. Whole plant water status and non-structural carbohydrates under progressive drought in a Caatinga deciduous woody species. Trees, v.34, n.4, 2021. https://doi.org/10.1007/s00468-021-02113-y

Silva EC, Albuquerque MB, Azevedo Neto AD, Silva Junior CD. Drought and Its Consequences to Plants - From Individual to Ecosystem. Responses of Organisms to Water Stress. São Cristóvão, p.17-47, 2013. https://doi.org/10.5772/53833

Silva JMC, Barbosa LCF, Leal IR, Tabarelli, M. The Caatinga: Understanding the challenges. Caatinga: The largest tropical dry forest region in South America, p.3-19, 2017.

Silva PLK, Dos Santos EAV, Dos Anjos CS, Silva KN. Anatomia foliar de Ceiba glaziovii k. Schum. (MalvaceaeBombacoideae), uma espécie medicinal da caatinga. I Congresso Internacional da diversidade do semiárido. Anais I. Realize Editora, 2016. Disponível em: https://www.editorarealize.com.br/index.php/artigo/visualizar/23485> Acesso em: 17 mai. 2021.

Souza BI, Menezes R, Camara AR. Efeitos da desertificação na composição de espécies do bioma Caatinga, Paraíba/Brasil. Investigaciones Geográficas, n.88, p.45-59, 2015. https://doi.org/10.14350/rig.44092

Souza LVS, Azevedo DO, De Carvalho AJA, Simões WL, Voltolini TV. Qualidade nutricional de plantas forrageiras de ocorrência na caatinga. Enciclopédia Biosfera, v.9, n.16, p.178-185, 2013.

Taiz L, Zeiger E, Moller I, Murphy A. Fisiologia e desenvolvimento vegetal. 6. ed, Artmed, 888p. 2017.

Valladares F, Aranda I, Arrieta S. Shade tolerance, photo inhibition sensitivity and phenotypic plasticity of Ilex aquifolium in continental Mediterranean sites. Tree Physiology, v.25, n.8 p.1041-1052, 2005. https://doi.org/10.1093/treephys/25.8.1041

Zhao Y, Cao H, Xu W, Chen G, Lian J, Du Y, Ma K. Contributions of precipitation and temperature to the large scale geographic distribution of fleshy-fruited plant species: Growth form matters. Scientific reports, v.8, 2018. https://doi.org/10.1038/s41598-018-35436-x 